\title{
The unfinished saga of invasive procedures for secondary mitral regurgitation
}

\author{
Daniel Grinberg', William Uhlrich², Sophie Thivolet ${ }^{2}$, Rémi Buzzi ${ }^{1}$, Gilles Rioufol' ${ }^{2}$, \\ Jean Francois Obadia ${ }^{1}$, Matteo Pozzi ${ }^{1}$ \\ ${ }^{1}$ Department of Cardiac Surgery, "Louis Pradel” Cardiologic Hospital, Lyon, France; ${ }^{2}$ Department of Cardiology, "Louis Pradel” Cardiologic \\ Hospital, Lyon, France \\ Correspondence to: Daniel Grinberg. Department of Cardiac Surgery, "Louis Pradel” Cardiologic Hospital, 28 Avenue du Doyen Lépine, 69500 Lyon, \\ France. Email: daniel.grinberg.pro@gmail.com.
}

\begin{abstract}
Secondary mitral regurgitation (MR) is a common valvular heart disease. Its prognostic burden in patients suffering from idiopathic or ischemic cardiomyopathy (ICM) with left ventricular (LV) dysfunction/dilation has been clearly demonstrated. Severe secondary MR is associated with an increased mortality and frequent heart failure hospitalizations. Although guideline-directed medical therapy (GDMT) is the cornerstone of the management of secondary MR, a certain proportion of patients remain symptomatic. For these patients, several surgical techniques have been progressively developed during the last few decades (replacement, repair, sub-valvular apparatus interventions and other ventricular approaches). In the absence of evidencebased medicine, the benefits of these surgical procedures remains controversial, leading to a low level of recommendation in the guidelines. One way to anticipate the future is to look to the past. Recent prospective randomized trials evaluated surgical and percutaneous techniques and led to a better understanding of how best to treat this disease. In this article, we aim to describe the saga of the surgical and percutaneous treatments for secondary MR throughout the previous decades.
\end{abstract}

Keywords: Secondary mitral regurgitation (secondary MR); mitral valve repair (MVr); mitral valve replacement (MVR); percutaneous procedures; MitraClip

Submitted Apr 04, 2020. Accepted for publication Aug 10, 2020.

doi: 10.21037/acs-2020-mv-15

View this article at: http://dx.doi.org/10.21037/acs-2020-mv-15

\section{Introduction}

The ancient functional mitral regurgitation (MR), today defined as secondary $M R$, is a common valvular heart disease resulting from idiopathic or ischemic cardiomyopathy (ICM) with left ventricular (LV) dysfunction/dilation (1). The prognostic implications of secondary MR have been clearly demonstrated showing a strong association between the severity of MR and mortality as well as heart failure hospitalizations $(2,3)$. Although guideline-directed medical therapy (GDMT) is the cornerstone of the management of secondary MR, a high proportion of patients remain quite symptomatic despite a maximal GDMT. The role of mitral valve (MV) surgery is still controversial as a consequence of limited available data, which has resulted in guidelines recommending surgery with low levels of evidence $(4,5)$. Nevertheless, several techniques (replacement, repair, subvalvular apparatus interventions and other ventricular approaches) have been adopted over time, however, no solution has proved superior to another or altered the natural history of the underlying cardiomyopathy (6).

The best way to anticipate the future is to look to the past. In this article, we aim to describe the saga of the surgical and percutaneous treatments for secondary MR throughout the previous decades.

\section{0s: the "pop-off valve" theory}

For many years, it was believed that the MV anatomofunctional complex had a beneficial "pop-off" function 
in advanced heart failure, which should be preserved. Surgical correction of MR in end-stage LV dysfunction was considered deleterious and responsible for prohibitive morbidity and mortality (7).

\section{Early 2000s: "undersized rigid annuloplasty for everybody"}

The "pop-off valve" hypothesis was soon challenged by "the Bolling theory", which promoted the efficiency of undersized annuloplasty. In 1996, Bolling's team showed for the first-time reasonable mortality when a surgical undersized annuloplasty was performed for severely symptomatic patients with LV ejection fraction (LVEF) $<25 \%$. The technique was deemed to reverse the vicious cycle while restoring valvular competency, alleviating the excessive ventricular workload and improving ventricular function (8). All cohort studies conducted during this decade revealed reasonable operative mortality in this population (1.6\% to $8.2 \% 30$-day mortality) $(9,10)$. The technique also should have promoted durable $\mathrm{LV}$ reverse remodelling and improved functional class. This theory was reinforced by the results of in vivo studies (ischemic sheep model) showing a decrease in LV radius curvature at the basal, equatorial and apical levels following restrictive annuloplasty. Thus, for the first time, the paramount importance of maintaining the integrity of annular and subvalvular continuity during MV surgery was highlighted and it was assumed that prohibitive morbidity associated with surgical correction could be attributed to the loss of the subvalvular apparatus (rather than the loss of the "pop-off valve"). Therefore, MV repair (MVr) was always recommended over replacement. This benefit was reported (I) in both ischemic and non-ischemic patients and (II) when MV surgery was associated with coronary artery bypass grafting (CABG) surgery (11).

In this specific setting, rigid rings were preferred to fix both inter-trigonal distance and septal-lateral dimension (12). Indeed, in the mid 2000s, the gold standard in functional MR (which, later, was reclassified as secondary MR) was the annulus remodelling by a restrictive annuloplasty (downsized by 2 to 4 sizes) with a nonflexible ring (rather than flexible band) regardless of the cardiomyopathy etiology. This position was supported by both American and European guidelines in 2006 and 2007 despite a total lack of analysis comparing surgery in conjunction with medical treatment versus medical treatment alone (class IC and IIaC, respectively) $(13,14)$.

\section{Late 2000s: disappointing time for surgical MVr}

As early as 2005, Bolling's team raised initial doubts concerning the real benefits for survival conferred by MV annuloplasty (MVA) for significant MR with severe LV dysfunction after 10 years of promoting a proactive approach in patients with secondary MR (15). The promising initial results were discounted by arguments of heterogeneous ring selection, an insufficient annular downsizing and the lack of reported data on the presence of recurrent MR at follow-up (16).

In the late 2000s, Magne et al. compared MV replacement (MVR) versus MVr, both associated with CABG surgery, in ischemic patients (17). Data suggested that MVr was not superior to MVR with regard to operative and overall mortality. Most importantly, this survival equivalence at long-term follow-up (12 years) was found regardless of the MR recurrence rate in the repair group- $45 \%$ of $\mathrm{MVr}$ patients had at least mild MR (Figure 1). Since patients with persistent MR despite $\mathrm{MVr}$ had the same survival rate as patients with no recurrent MR, the question of the clinical impact of treating secondary MR was raised. Additional doubts were set forth by large retrospective studies analysing CABG alone versus CABG in conjunction with MVA in ischemic patients who were candidates for CABG surgery. Several studies suggested no clear demonstrable survival benefit conferred by MVA as the poor prognosis was related to the underlying cardiomyopathy rather than to the mitral surgery $(21,22)$. A sudden shock wave passed through the cardiovascular surgery field and it became increasingly questionable if modern surgical strategies could really improve patients' prognosis when compared to medical therapy alone. Finally, most of the publications that shaped recommendations (even the current ones) were single-centre, retrospective studies including small populations with heterogeneous patients (primary and secondary MR, ischemic and non-ischemic secondary $M R$, broad inclusion criteria regardless of selection on LV dimensions). Moreover, most studies reported the retrospective results of a single treatment (surgery) with no control group. Thus, "evidence based medicine" had not yet reached the surgical world.

\section{Early 2010s: surgeons want to understand, but...}

In order to provide strong evidence-based recommendations and possibly stimulated by the fast development of percutaneous techniques, considerable efforts were made 


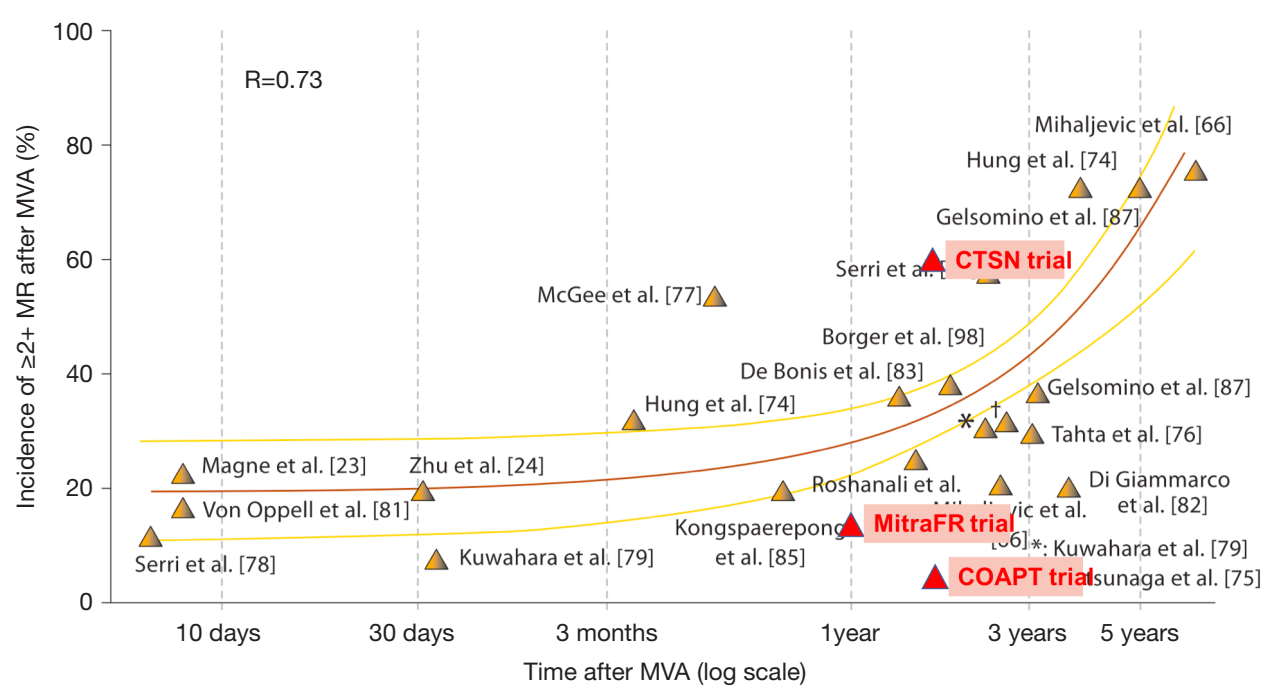

Figure 1 The Achilles' heel of MVr: the recurrence of MR after MVr increases with time. In this figure, adapted from Magne et al. (17), we have added in red the high recurrence of MR after surgical repair [60\% in the CTSN trial (18)] and the lower recurrence after percutaneous repair [17\% in MITRA.FR and 5\% in COAPT $(19,20)]$. MVr, mitral valve repair; MR, mitral regurgitation.

\begin{tabular}{|c|c|c|}
\hline & Ischemic & Non-ischemic \\
\hline Mechanism & $\begin{array}{l}\text { LV remodelling and dysfunction; annular dilation/ } \\
\text { dysfunction; mechanical dyssynchrony }\end{array}$ & LV remodelling; annular dilation \\
\hline $\begin{array}{l}\text { Natural } \\
\text { history }\end{array}$ & \multicolumn{2}{|c|}{$\begin{array}{l}\text { It remains hard to determine if secondary MR occurs when cardiomyopathies are more severe or if the occurrence of a } \\
\text { secondary MR makes the underlying cardiomyopathy more severe }\end{array}$} \\
\hline \multirow{3}{*}{$\begin{array}{l}\text { Common } \\
\text { features }\end{array}$} & Up to $50 \%$ of cases after $\mathrm{AMI}$ & Up to $75 \%$ of patients with heart-failure symptoms \\
\hline & Moderate or severe in only $10-12 \%$ & Moderate to severe in only $25 \%$ \\
\hline & Independent of initial LVEF or LV dimensions & More LV dilatation and worse LVEF \\
\hline
\end{tabular}

MR, mitral regurgitation; LV, left ventricular; AMI, acute myocardial infarction; LVEF, left ventricular ejection fraction.

by surgeons to identify the best candidates for the invasive correction of secondary MR and to choose the best surgical strategies for this population. Table 1 shows the differences between ischemic and non-ischemic secondary MR.

\section{Secondary MR complicating ICM}

Most data concerned patients with ICM, especially patients awaiting surgical coronary revascularization, since adding a mitral procedure during CABG surgery had been the standard of care for decades (23). Three subsets of ischemic patients were identified:

(I) Candidates for CABG with severe secondary MR: a randomized study was performed in the US by the Cardiothoracic Surgical Trials Network (CTSN) to compare $\mathrm{MVr}$ and MVR over a 12 -month follow-up period (18). The authors found no significant difference in $\mathrm{LV}$ end-systolic volume index (LVESVI), remodelling or survival between both groups. Two other major takeaways were also identified: (I) the composite major adverse event (rate of death, stroke, subsequent MV surgery, hospitalization for heart failure or an increase in New York Heart Association class of $\geq 1$ ) occurred in up to $30 \%$ of patients at 1 -year follow-up, highlighting the large potential for improvement 
in the therapy of ischemic secondary MR; and (II) the investigators found a MR recurrence ( $\geq$ grade 2) rate at 2 years of $60 \%$ after MVr. Thus, if the persistence of MR had no impact on the survival, the usefulness of treating secondary MR would be challenged. In the subgroup of CABG surgery candidates with severe ischemic MR, no prospective study compared CABG surgery with MR correction versus CABG surgery without MR correction for understandable ethical reasons.

(II) Candidates for CABG with moderate secondary MR [defined as an effective regurgitant orifice (ERO) area of 0.20 to $\left.0.39 \mathrm{~cm}^{2}\right]$ and good LV ejection function (LVEF $>30 \%$ ): in 2012, the Randomized Ischemic Mitral Evaluation (RIME) investigators in Europe proposed to randomize patients referred for CABG surgery with moderate ischemic $\mathrm{MR}$ to undergo $\mathrm{CABG}+\mathrm{MVr}$ or $\mathrm{CABG}$ alone (24). The study was stopped early after the 1 -year interim data analysis showed a greater improvement in the primary endpoint (peak oxygen consumption) in the CABG + MVr group. In these patients, adding a mitral annuloplasty to CABG was also associated with a greater $\mathrm{LV}$ reverse remodelling and a decrease in MR severity. However, no improvement of survival at 1 year could be identified. In the subgroup of patients with mild ischemic MR, there was no evidence that adding a $\mathrm{MVr}$ to surgical revascularization improved the long-term survival (25).

(III) Candidates for CABG with poor LV function: in patients with $L V$ dysfunction and moderate to severe $M R$, adding a $M V r$ to $C A B G$ may improve survival compared with CABG alone or medical therapy alone (26).

\section{Secondary MR in non-ICM (N-ICM)}

Conversely, secondary MR in non-ischemic patients occurs more often where there is a reduced LVEF. This population is less studied probably because proposing a surgery to frail patients without CABG indication appears to be risky. Preliminary results comparing mitral surgery and medical therapy in "historical patients" with catastrophic LV parameters suggested a benefit of surgical correction of MR in terms of survival and LV remodelling (11). Thus, both patients' characteristics and modern non-surgical therapy dramatically changed in the last 15 years and this literature should be carefully interpreted. Recent retrospective data showed that postoperative survival was conditioned by the restoration of a LV forward stroke volume (27). Thus, no specific preoperative clinical or echocardiographic prognostic parameters were identified. As of today, surgery is an option with a IIb class of recommendation. This subset of patients probably will be less often referred to surgery and is a possible target for innovative therapies.

Finally, after more than 20 years of fine-tuning, no significant evidence supports a systematic adoption of surgical treatment of secondary MR. Table S1 summarizes the most significant published studies regarding secondary MR.

\section{Late 2010s: one confirmation (MITRA.FR) and one cat among pigeons (COAPT)}

Based on the encouraging results of the surgical edgeto-edge technique (28-30), percutaneous, transcatheter procedures with the MitraClip (Abbott Vascular, Santa Clara, California) were proposed (31).

In 2011, the EVEREST II trial concluded that MitraClip implantation is safe and feasible and further concluded that MitraClip implication reduced symptoms and improved the clinical status of secondary MR in a series with only $30 \%$ of secondary MR patients (32). Due to the design of the study, the efficacy of the MitraClip was judged non-inferior to $\mathrm{MVr}$ despite a reoperation rate of $22 \%$ in the MitraClip group vs. $2 \%$ in the surgical group (33). Thus, by 2012, the potential use of percutaneous edge-to-edge procedures in secondary MR was mentioned in European guidelines (without specific indications) (34).

In August 2018, the results of the MITRA.FR randomized controlled trial were presented, comparing a group receiving GDMT versus a group of MitraClip + GDMT in a population of heart failure patients with secondary MR (19). The study showed an absence of benefit in the primary endpoint (death from any cause or rehospitalisation for heart failure) and in any sub-group analysis. These results were in total accordance with all previous literature and, in particular, when we compared the curve of MITRA.FR with the propensity matched series of Wu et al. (15) (Figure 2).

In November 2018, surprising results were announced in the COAPT study showing for the first time in the history of secondary MR treatment a major benefit of MitraClip implantation on the primary endpoint (cumulative incidence of rehospitalisation for heart failure), on mortality and in 

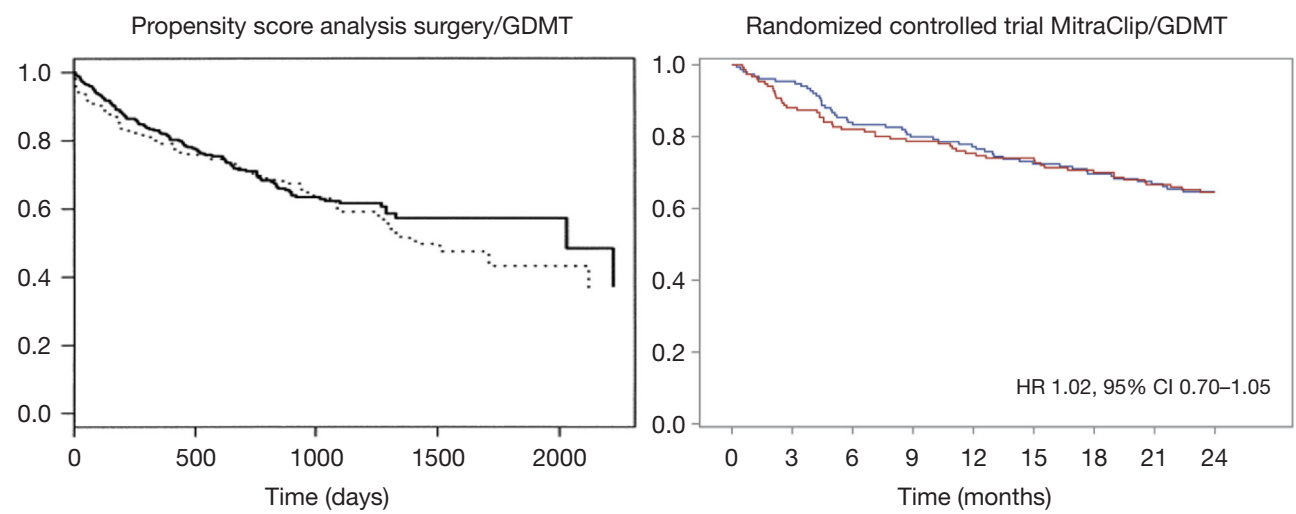

Figure 2 Similarity of results after surgery in 2005 (left) and percutaneous treatment in 2018 (right) of secondary MR. (Left) In 2005, the results in terms of morbidity and mortality of the surgical correction of secondary MR in addition to GDMT (solid line) were not better in a propensity score analysis of a comparative group of patients treated with GDMT only (dotted line) (15); (right) in 2018, the MITRA.FR randomized controlled trial seems to confirm this result with no benefit in adding the percutaneous treatment (red line) to GDMT (blue line) (19). MR, mitral regurgitation; GDMT, guideline-directed medical therapy.

any sub-group analysis (20).

These apparently contradictory results created a "buzz" in the cardiology community. Hundreds of publications were subsequently published to analyze this discrepancy. Despite similar LVEFs (33.3\% vs. $31.3 \%$ in MITRA.FR and COAPT, respectively), the severity of regurgitation was higher in the COAPT study $\left(0.31 v s .0 .41 \mathrm{~cm}^{2}\right)$ and $\mathrm{LV}$ volumes less dilated (192 vs. $251 \mathrm{~mL})$. This apparent discrepancy led to the rethinking of the definition of secondary MR with the proportionate/disproportionate concept, which had the advantage of reconciling the results of the two studies (35).

After the publication of the COAPT study, in March 2019, the Food and Drug Administration (FDA) approved the MitraClip for the treatment of secondary MR in the U.S. and implantations of MitraClip increased dramatically worldwide. Currently, implantation of MitraClip is the only procedure (surgical or percutaneous) with a proven benefit; in addition to medical treatment, in the treatment of secondary MR. It now is the gold standard against which any new device will be compared. Several new percutaneous repair or replacement techniques (36-43) are the subject of a dedicated keynote lecture and will not be discussed herein, but will be discussed in detail in another chapter of this issue.

\section{What's next?}

There is no doubt that GDMT, including cardiac resynchronization therapy and myocardial revascularization, should systematically be considered as the first line of treatment in patients with secondary MR complicating heart failure regardless of the LVEF (44). The remaining patients unresponsive to GDMT (60\%) as well as those developing secondary MR despite GDMT have the worst prognosis and should be evaluated by a "Valvular Heart Team" and possibly recommended to correct their secondary MR. Every case must be analyzed by integrating both MR quantification and LV analysis (etiology, viability, function, volume). The old definitions of secondary MR, as described in the previous guidelines, should be revisited taking into account the LV geometry ("proportionate/disproportionate theory") (45). Although very appealing, this classification model is yet to be validated and, even more important, it is necessary to understand how it will help the decisionmaking for every single patient.

The proper recommendations summarized in Figure 3 should be revisited. New Guidelines are expected in the U.S. in 2020 and in Europe in 2021 and they should take into account the main lessons of the past decades, which are as follows:

(I) Heart failure with secondary MR is a severe disease with a prognosis worsening with the severity of the regurgitation;

(II) All literature strongly suggests that GDMT including cardiac resynchronization therapy and myocardial revascularization should be the first line of treatment for any secondary MR; 


\begin{tabular}{|c|c|c|c|c|c|c|c|}
\hline & & & & ESC 2012 & ESC 2017 & AHA/ACC 2014 & AHA/ACC 2017 \\
\hline \multirow{5}{*}{$\begin{array}{l}\text { Severe } \\
\text { SMR }\end{array}$} & \multirow{3}{*}{$\begin{array}{l}\text { LVEF } \\
>30 \%\end{array}$} & \multicolumn{2}{|c|}{ Patient undergoing CABG surgery } & \multicolumn{2}{|c|}{$\begin{array}{l}\text { SURGERY } \\
\quad \text { I- C }\end{array}$} & \multicolumn{2}{|c|}{$\begin{array}{l}\text { SURGERY } \\
\text { Ila - C }\end{array}$} \\
\hline & & \multirow{2}{*}{$\begin{array}{c}\text { No option for } \\
\text { revascularization } \\
\text { BUT } \\
\text { symptoms despite GDMT }\end{array}$} & Low surgical risk & \multicolumn{2}{|c|}{$\begin{array}{l}\text { SURGERY } \\
\text { IIb - C }\end{array}$} & \multirow{4}{*}{$\begin{array}{c}\text { SURGERY } \\
(\mathrm{MVR}=\mathrm{MVr}) \\
\text { Ilb - C }\end{array}$} & \multirow{4}{*}{$\begin{array}{c}\text { SURGERY } \\
\text { (MVR }>\text { annuloplasty) } \\
\text { Ilb - C }\end{array}$} \\
\hline & & & $\begin{array}{c}\text { No low surgical risk } \\
\text { AND suitable } \\
\text { morphology }\end{array}$ & & $\begin{array}{l}\mathrm{E} 2 \mathrm{E} \\
\mathrm{Ilb}-\mathrm{C}\end{array}$ & & \\
\hline & \multirow{2}{*}{$\begin{array}{l}\text { LVEF } \\
<30 \%\end{array}$} & \multicolumn{2}{|c|}{$\begin{array}{l}\text { Viability with Option for revascularization } \\
\text { AND symptoms despite GDMT }\end{array}$} & \multicolumn{2}{|c|}{$\begin{array}{l}\text { SURGERY } \\
\text { Ila - C }\end{array}$} & & \\
\hline & & \multicolumn{2}{|c|}{ No option for revascularization } & & $\begin{array}{l}\mathrm{E} 2 \mathrm{E} \\
\mathrm{Ilb}-\mathrm{C}\end{array}$ & & \\
\hline $\begin{array}{l}\text { Moderate } \\
\text { SMR }\end{array}$ & \multicolumn{3}{|c|}{ Patient undergoing $C A B G$} & $\begin{array}{l}\text { SURGERY } \\
\text { considered } \\
\text { Ila - C }\end{array}$ & & $\begin{array}{l}\text { MVr my be } \\
\text { considered } \\
\text { Ilb - C }\end{array}$ & $\begin{array}{l}\text { Usefulness of MVr } \\
\text { UNCERTAIN } \\
\text { Ilb - B-R }\end{array}$ \\
\hline
\end{tabular}

Figure 3 Evolution of European and American guidelines in the management of secondary MR. ACC, American College of Cardiology; AHA, American Heart Association; CABG, coronary artery bypass graft; ESC, European Society of Cardiology; GDMT, guideline-directed medical therapy; LVEF, left ventricular ejection fraction; MR, mitral regurgitation; MVR, mitral valve replacement; OMM, optimal medical management; SMR, secondary mitral regurgitation.

(III) The definition of secondary MR should be revisited, integrating the regurgitation in its ventricular environment (size and function);

(IV) In candidates for surgical myocardial revascularization, the indication for treating severe secondary MR with such surgical procedure is still recommended by the guidelines, which seems logical, but one must note that we have no trials supporting this recommendation and we probably will never have such support;

(V) With respect to N-ICM, the benefit of the surgical treatment of secondary MR has never been confirmed by evidence-based medicine, so that such surgery will probably be rare and limited (i) to significant secondary MR associated with other surgical procedures or (ii) when other percutaneous procedures are impossible and when $\mathrm{LV}$ function is not too low or (iii) as an alternative to transplantation or long-term mechanical circulatory support;

(VI) In patients contraindicated for surgery, COAPT indicates that the treatment of secondary MR can save lives and improve quality of life in a highly selective group of secondary MR patients. COAPT and MITRA.FR confirm that the MitraClip technique is safe and efficient in reducing the severity of the regurgitation and better than the majority of the surgical series suggesting that the edge-to-edge technique is particularly adapted for the treatment of this disease (Figure 2). MITRA. FR shows the limits of over indication of MitraClip implantation, in particular, when the ventricles are too dilated and the regurgitation too low (the best way to kill a technique is to overuse it);

(VII) The Achilles' heel of valve repair being the high risk of recurrence of MR, a wider place for MVR (surgical or percutaneous) is expected, in particular, when the tethering is important and the edge-toedge technique is unsuitable.

\section{Conclusions}

Looking back through the past decades of the history of secondary MR shows the progress in understanding this complex disease and better defines its phenotype and treatment. The poor prognosis of secondary MR is confirmed and directly linked to the severity of the regurgitation, justifying an aggressive approach starting with a GDMT. The place of surgical treatment has always been a matter of controversy as reflected in recent studies which 
have never been able to confirm its efficacy. Conversely, percutaneous treatment has, for the first time, established the concept of a possible virtuous cycle after correction of a severe secondary MR. An opposite randomized controlled trial shows that this benefit is possible only in a very accurately selected population. The challenge for the future will be to define which phenotype of patients and which definition of secondary MR (severity of MR/ventricular remodelling) could actually benefit from correction. New randomized controlled studies are expected to answer these questions, in particular, at an earlier phase of the disease.

\section{Acknowledgments}

Funding: None.

\section{Footnote}

Conflicts of Interest: JFO: Received research support from Boehringer, Abbott, Medtronic, Edwards. Received Consulting Fees/Honoraria from Edwards, Medtronic, Servier, Novartis. Received Royalty Income from Landanger, Delacroix-Chevalier. The other authors have no conflicts of interest to declare.

Open Access Statement: This is an Open Access article distributed in accordance with the Creative Commons Attribution-NonCommercial-NoDerivs 4.0 International License (CC BY-NC-ND 4.0), which permits the noncommercial replication and distribution of the article with the strict proviso that no changes or edits are made and the original work is properly cited (including links to both the formal publication through the relevant DOI and the license). See: https://creativecommons.org/licenses/by-nc-nd/4.0/.

\section{References}

1. Asgar AW, Mack MJ, Stone GW. Secondary mitral regurgitation in heart failure: pathophysiology, prognosis, and therapeutic considerations. J Am Coll Cardiol 2015;65:1231-48.

2. Trichon BH, Felker GM, Shaw LK, et al. Relation of frequency and severity of mitral regurgitation to survival among patients with left ventricular systolic dysfunction and heart failure. Am J Cardiol 2003;91:538-43.

3. Rossi A, Dini FL, Faggiano P, et al. Independent prognostic value of functional mitral regurgitation in patients with heart failure. A quantitative analysis of
1256 patients with ischaemic and nonischaemic dilated cardiomyopathy. Heart 2011;97:1675-80.

4. Nishimura RA, Otto CM, Bonow RO, et al. 2017 AHA/ ACC Focused Update of the 2014 AHA/ACC Guideline for the management of patients with valvular heart disease: a report of the American College of Cardiology/American Heart Association Task Force on Clinical Practice Guidelines. J Am Coll Cardiol 2017;70:252-89.

5. Baumgartner H, Falk V, Bax JJ, et al. 2017 ESC/EACTS Guidelines for the management of valvular heart disease. Eur Heart J 2017;38:2739-91.

6. Calafiore AM, Iaco AL, Gallina S, et al. Surgical treatment of functional mitral regurgitation. Int J Cardiol 2013;166:559-71.

7. Braunwald E. A Textbook of Cardiovascular Medicine. 4th ed. Philadelphia: Saunders, 1992.

8. Bach DS, Bolling SF. Improvement following correction of secondary mitral regurgitation in end-stage cardiomyopathy with mitral annuloplasty. Am J Cardiol 1996;78:966-9.

9. Bax JJ, Braun J, Somer ST, et al. Restrictive annuloplasty and coronary revascularization in ischemic mitral regurgitation results in reverse left ventricular remodeling. Circulation 2004;110:II103-8.

10. Badhwar V, Bolling SF. Mitral valve surgery in the patient with left ventricular dysfunction. Semin Thorac Cardiovasc Surg 2002;14:133-6.

11. Acker MA, Bolling S, Shemin R, et al. Mitral valve surgery in heart failure: insights from the Acorn Clinical Trial. J Thorac Cardiovasc Surg 2006;132:568-77.

12. Spoor MT, Geltz A, Bolling SF. Flexible versus nonflexible mitral valve rings for congestive heart failure: differential durability of repair. Circulation 2006;114:I67-71.

13. Bonow RO, Carabello BA, Kanu C, et al. ACC/AHA 2006 guidelines for the management of patients with valvular heart disease: a report of the American College of Cardiology/American Heart Association Task Force on Practice Guidelines (writing committee to revise the 1998 Guidelines for the Management of Patients With Valvular Heart Disease): developed in collaboration with the Society of Cardiovascular Anesthesiologists: endorsed by the Society for Cardiovascular Angiography and Interventions and the Society of Thoracic Surgeons. Circulation 2006;114:e84-231.

14. Vahanian A, Baumgartner H, Bax J, et al. Guidelines on the management of valvular heart disease: The Task Force on the Management of Valvular Heart Disease of the European Society of Cardiology. Eur Heart J 
2007;28:230-68.

15. Wu AH, Aaronson KD, Bolling SF, et al. Impact of mitral valve annuloplasty on mortality risk in patients with mitral regurgitation and left ventricular systolic dysfunction. J Am Coll Cardiol 2005;45:381-7.

16. McGee EC, Gillinov AM, Blackstone EH, et al. Recurrent mitral regurgitation after annuloplasty for functional ischemic mitral regurgitation. J Thorac Cardiovasc Surg 2004;128:916-24.

17. Magne J, Sénéchal M, Dumesnil JG, et al. Ischemic mitral regurgitation: a complex multifaceted disease. Cardiology 2009; 112:244-59.

18. Acker MA, Parides MK, Perrault LP, et al. Mitral-valve repair versus replacement for severe ischemic mitral regurgitation. N Engl J Med 2014;370:23-32.

19. Obadia JF, Messika-Zeitoun D, Leurent G, et al. Percutaneous repair or medical treatment for secondary mitral regurgitation. N Engl J Med 2018;379:2297-306.

20. Stone GW, Lindenfeld J, Abraham WT, et al. Transcatheter mitral-valve repair in patients with heart failure. N Engl J Med 2018;379:2307-18.

21. Mihaljevic T, Lam BK, Rajeswaran J, et al. Impact of mitral valve annuloplasty combined with revascularization in patients with functional ischemic mitral regurgitation. J Am Coll Cardiol 2007;49:2191-201.

22. Crabtree TD, Bailey MS, Moon MR, et al. Recurrent mitral regurgitation and risk factors for early and late mortality after mitral valve repair for functional ischemic mitral regurgitation. Ann Thorac Surg 2008;85:1537-42.

23. Castleberry AW, Williams JB, Daneshmand MA, et al. Surgical revascularization is associated with maximal survival in patients with ischemic mitral regurgitation: a 20-year experience. Circulation 2014;129:2547-56.

24. Chan KM, Punjabi PP, Flather M, et al. Coronary artery bypass surgery with or without mitral valve annuloplasty in moderate functional ischemic mitral regurgitation: final results of the Randomized Ischemic Mitral Evaluation (RIME) trial. Circulation 2012;126:2502-10.

25. Kang DH, Kim MJ, Kang SJ, et al. Mitral valve repair versus revascularization alone in the treatment of ischemic mitral regurgitation. Circulation 2006;114:1499-503.

26. Deja MA, Grayburn PA, Sun B, et al. Influence of mitral regurgitation repair on survival in the surgical treatment for ischemic heart failure trial. Circulation 2012;125:2639-48.

27. Kamperidis V, van Wijngaarden SE, van Rosendael PJ, et al. Restrictive mitral valve annuloplasty: prognostic implications of left ventricular forward flow. Ann Thorac
Surg 2017;104:1464-70.

28. Alfieri O, Maisano F, De Bonis M, et al. The doubleorifice technique in mitral valve repair: a simple solution for complex problems. J Thorac Cardiovasc Surg 2001;122:674-81.

29. De Bonis M, Lapenna E, La Canna G, et al. Mitral valve repair for functional mitral regurgitation in endstage dilated cardiomyopathy: role of the "edge-to-edge" technique. Circulation 2005;112:I402-8.

30. Goel SS, Bajaj N, Aggarwal B, et al. Prevalence and outcomes of unoperated patients with severe symptomatic mitral regurgitation and heart failure: comprehensive analysis to determine the potential role of MitraClip for this unmet need. J Am Coll Cardiol 2014;63:185-6.

31. Condado JA, Acquatella H, Rodriguez L, et al. Percutaneous edge-to-edge mitral valve repair: 2-year follow-up in the first human case. Catheter Cardiovasc Interv 2006;67:323-5.

32. Feldman T, Foster E, Glower DD, et al. Percutaneous repair or surgery for mitral regurgitation. $\mathrm{N}$ Engl J Med 2011;364:1395-406.

33. Mauri L, Foster E, Glower DD, et al. 4-year results of a randomized controlled trial of percutaneous repair versus surgery for mitral regurgitation. J Am Coll Cardiol 2013;62:317-28.

34. Vahanian A, Alfieri O, Andreotti F, et al. Guidelines on the management of valvular heart disease (version 2012). Eur Heart J 2012;33:2451-96.

35. Grayburn PA, Sannino A, Packer M. Proportionate and disproportionate functional mitral regurgitation: a new conceptual framework that reconciles the results of the MITRA-FR and COAPT Trials. JACC Cardiovasc Imaging 2019;12:353-62.

36. Feldman T, Young A. Percutaneous approaches to valve repair for mitral regurgitation. J Am Coll Cardiol 2014;63:2057-68

37. Weber M, Öztürk C, Taramasso M, et al. Leaflet edgeto-edge treatment versus direct annuloplasty in patients with functional mitral regurgitation. EuroIntervention 2019;15:912-8.

38. Nickenig G, Schueler R, Dager A, et al. Treatment of chronic functional mitral valve regurgitation with a percutaneous annuloplasty system. J Am Coll Cardiol 2016;67:2927-36.

39. Cerny S, Benesova M, Skalsky I, et al. Persistent reduction of mitral regurgitation by implantation of a transannular mitral bridge: durability and effectiveness of the repair at 2 years-results of a prospective trial. Eur J Cardiothorac 
Surg 2019;55:867-73.

40. Kim JH, Kocaturk O, Ozturk C, et al. Mitral cerclage annuloplasty, a novel transcatheter treatment for secondary mitral valve regurgitation: initial results in swine. J Am Coll Cardiol 2009;54:638-51.

41. Regueiro A, Granada JF, Dagenais F, et al. Transcatheter mitral valve replacement: insights from early clinical experience and future challenges. J Am Coll Cardiol 2017;69:2175-92.

42. Del Val D, Ferreira-Neto AN, Wintzer-Wehekind J, et al. Early experience with transcatheter mitral valve replacement: a systematic review. J Am Heart Assoc

Cite this article as: Grinberg $\mathrm{D}$, Uhlrich $\mathrm{W}$, Thivolet $\mathrm{S}$, Buzzi R, Rioufol G, Obadia JF, Pozzi M. The unfinished saga of invasive procedures for secondary mitral regurgitation. Ann Cardiothorac Surg 2021;10(1):66-74. doi: 10.21037/acs-2020mv-15 2019;8:e013332.

43. Sorajja P, Moat N, Badhwar V, et al. Initial feasibility study of a new transcatheter mitral prosthesis: the first 100 patients. J Am Coll Cardiol 2019;73:1250-60.

44. Nasser R, Van Assche L, Vorlat A, et al. Evolution of functional mitral regurgitation and prognosis in medically managed heart failure patients with reduced ejection fraction. JACC Heart Fail 2017;5:652-9.

45. Grayburn PA, Carabello B, Hung J, et al. Defining 'severe' secondary mitral regurgitation: Emphasizing an integrated approach. J Am Coll Cardiol 2014;64:2792-801. 


\section{References}

46. Salmasi MY, Harky A, Chowdhury MF, et al. Should the mitral valve be repaired for moderate ischemic mitral regurgitation at the time of revascularization surgery? J Card Surg 2018;33:374-84.

47. Michler RE, Smith PK, Parides MK, et al. Two-year outcomes of surgical treatment of moderate ischemic mitral regurgitation. N Engl J Med 2016;374:1932-41.

48. Kamperidis V, Van Wijngaarden SE, Van Rosendael PJ, et al. Mitral valve repair for secondary mitral regurgitation in non-ischaemic dilated cardiomyopathy is associated with left ventricular reverse remodelling and increase of forward flow. Eur Heart J Cardiovasc Imaging 2018;19:208-15.

49. Calafiore AM, Di Mauro M, Gallina S, et al. Mitral valve surgery for chronic ischemic mitral regurgitation. Ann Thorac Surg 2004;77:1989-97.

50. Lee APW, Acker M, Kubo SH, et al. Mechanisms of recurrent functional mitral regurgitation after mitral valve repair in nonischemic dilated cardiomyopathy importance of distal anterior leaflet tethering. Circulation 2009;119:2606-14.

51. Magne J, Pibarot P, Dagenais F, et al. Preoperative posterior leaflet angle accurately predicts outcome after restrictive mitral valve annuloplasty for ischemic mitral regurgitation. Circulation 2007;115:782-91. 
Table S1 Details chart of some of the most significant published studies about secondary MR

\begin{tabular}{|c|c|c|c|c|c|c|c|c|c|c|c|c|c|c|c|c|}
\hline \multirow[b]{2}{*}{$\begin{array}{l}\text { Author } \\
\text { (ref.) }\end{array}$} & \multicolumn{3}{|l|}{ Study frame } & \multicolumn{3}{|c|}{ Etiology } & \multicolumn{3}{|l|}{ Severity } & \multicolumn{3}{|l|}{ LVEF } & \multicolumn{3}{|c|}{ LV dilatation } & \multirow[b]{2}{*}{ Conclusion } \\
\hline & Design & Groups & Population & ICM & $\mathrm{N}-\mathrm{ICM}$ & Comment & $\begin{array}{l}\text { Moderate } \\
\text { (ERO } \\
0.2-0.4)\end{array}$ & $\begin{array}{l}\text { Severe } \\
(\text { ERO } \\
\geq 0.4)\end{array}$ & Comment & $\begin{array}{l}\text { Good } \\
(\geq 35 \%)\end{array}$ & $\begin{array}{l}\text { Poor } \\
\text { (<35\%) }\end{array}$ & Comment & Yes & No & Comments & \\
\hline $\begin{array}{l}\text { Bax } \\
\text { et al. (9) }\end{array}$ & Retrospective & Single arm & $\begin{array}{l}51 \text { patients underwent } \mathrm{CABG} \\
\text { and restrictive annuloplasty }\end{array}$ & $x$ & & & $\mathrm{x}$ & $\mathrm{x}$ & $\begin{array}{l}\text { Mean } \\
\text { grade } 3.4\end{array}$ & & $\mathrm{x}$ & Mean 31\% & $\mathrm{x}$ & & $\begin{array}{l}\text { Mean LVEDD } \\
59 \text { and } 61 \mathrm{~mm}\end{array}$ & $\begin{array}{l}\text { Excellent results of combined restrictive } \\
\text { annuloplasty and CABG }\end{array}$ \\
\hline $\begin{array}{l}\text { Badhwar } \\
\text { et al. (10) }\end{array}$ & Retrospective & Single arm & $\begin{array}{l}125 \text { patients manage with } \\
\text { restrictive annuloplasty }\end{array}$ & $\mathrm{x}$ & $\mathrm{x}$ & N/A & & & N/A & & $\mathrm{x}$ & Mean $16 \%$ & $\mathrm{x}$ & & $\begin{array}{l}\text { Mean LVEDV } \\
281 \mathrm{~mL}\end{array}$ & $\begin{array}{l}\text { Mitral reconstruction offers a new treatment } \\
\text { strategy for patients with MR and end-stage } \\
\text { heart failure }\end{array}$ \\
\hline $\begin{array}{l}\text { Acker } \\
\text { et al. (11) }\end{array}$ & Retrospective & Comparative & $\begin{array}{l}193 \text { patients with MR surgery } \\
\text { (84\% annuloplasty and } 15 \% \\
\text { MVR). Corecap in } 50 \%\end{array}$ & & $\mathrm{x}$ & $6.2 \%$ are ICM & $x$ & $\mathrm{x}$ & $\begin{array}{l}58 \% \geq \\
\text { grade } 2\end{array}$ & & $\mathrm{x}$ & $\begin{array}{l}\text { Mean } \\
23.9 \%\end{array}$ & $\mathrm{x}$ & & $\begin{array}{l}\text { Mean LVEDV } \\
270.1 \mathrm{~mL}\end{array}$ & Clear benefit to the surgical elimination of MR \\
\hline $\begin{array}{l}\text { Spoor } \\
\text { et al. (12) }\end{array}$ & Retrospective & Comparative & 289 patients: BAND vs. RING & & & N/A & & & N/A & & $\mathrm{x}$ & $\begin{array}{l}\text { Mean LVEF } \\
17 \% \text { and } \\
21 \%\end{array}$ & & $\mathrm{x}$ & LVIDd 60 mm & $\begin{array}{l}\text { Use of a nonflexible ring appears to } \\
\text { significantly reduce the need for repeat } \\
\text { surgical procedures }\end{array}$ \\
\hline $\begin{array}{l}\text { McGee } \\
\text { et al. (16) }\end{array}$ & Retrospective & Single arm & $\begin{array}{l}257 \text { consecutive patients } \\
\text { undergoing } \mathrm{MVr}\end{array}$ & $\mathrm{x}$ & & $\begin{array}{l}95 \% \mathrm{CABG} \\
\text { associate }\end{array}$ & $\mathrm{x}$ & $\mathrm{x}$ & $\begin{array}{l}\geq 3+\text { in } \\
98.4 \%\end{array}$ & $\mathrm{x}$ & $\mathrm{x}$ & Mean 35\% & & & N/A & $\begin{array}{l}\text { Development of additional techniques is } \\
\text { necessary to achieve more secure repair of } \\
\text { functional ischemic MR }\end{array}$ \\
\hline $\begin{array}{l}\text { Mihaljevic } \\
\text { et al. (21) }\end{array}$ & Retrospective & Comparative & $\begin{array}{l}\text { CABG alone (100 patients) } \\
\text { and CABG + MVA ( } 290 \\
\text { patients) }\end{array}$ & $x$ & & $\begin{array}{l}100 \% \mathrm{CABG} \\
\text { associate }\end{array}$ & $x$ & $\mathrm{x}$ & $\begin{array}{l}\geq 3+\text { in } \\
100 \%\end{array}$ & $x$ & $\mathrm{x}$ & All $<45 \%$ & & & N/A & $\begin{array}{l}\text { MVA does not improve long-term functional } \\
\text { status or survival in patients with severe } \\
\text { functional ischemic MR }\end{array}$ \\
\hline $\begin{array}{l}\text { Wu } \\
\text { et al. (15) }\end{array}$ & Retrospective & Comparative & $\begin{array}{l}126 \text { MVA, } 263 \text { no MVA, } 293 \\
\text { candidates for MVA but not } \\
\text { performed }\end{array}$ & $x$ & $\mathrm{x}$ & $\begin{array}{l}\text { CABG } \\
\text { associate from } \\
51 \text { to } 71 \%\end{array}$ & & & N/A & & $\mathrm{x}$ & $\begin{array}{l}\text { Mean LVEF } \\
19 \% \text { to } \\
23 \%\end{array}$ & $\mathrm{x}$ & & $\begin{array}{l}\text { Mean LVEDD } \\
65 \mathrm{~mm}\end{array}$ & $\begin{array}{l}\text { No clearly demonstrable mortality benefit } \\
\text { conferred by MVA for significant MR with } \\
\text { severe LV dysfunction }\end{array}$ \\
\hline $\begin{array}{l}\text { Crabtree } \\
\text { et al. (22) }\end{array}$ & Retrospective & Single arm & $\begin{array}{l}257 \text { patients undergoing } \mathrm{MVr} \\
\text { for secondary MR }\end{array}$ & $\mathrm{x}$ & & $\begin{array}{l}85 \% \mathrm{CABG} \\
\text { associate }\end{array}$ & & & N/A & $\mathrm{x}$ & $\mathrm{x}$ & Mean 35\% & & & N/A & $\begin{array}{l}\text { Mortality for ischemic MR remains high } \\
\text { despite surgical management and may be } \\
\text { related to risk factors for progression of CAD }\end{array}$ \\
\hline $\begin{array}{l}\text { Castleberry } \\
\text { et al. (23) }\end{array}$ & Retrospective & Comparative & $\begin{array}{l}\text { 4,989 patients with CAD and } \\
\text { MR ( } 36 \% \text { medical treatment, } \\
25 \% \text { PCI, } 34 \% \text { CABG, } 5 \% \\
\text { CABG + MV surgery) }\end{array}$ & $x$ & & $\begin{array}{l}100 \% \\
\text { significant CAD }\end{array}$ & $x$ & $\mathrm{x}$ & $\begin{array}{l}\geq 2+\text { in } \\
100 \%\end{array}$ & $\mathrm{x}$ & $\mathrm{x}$ & $\begin{array}{l}\text { Mean from } \\
45 \% \text { to } \\
50 \%\end{array}$ & & & N/A & $\begin{array}{l}\text { Medical treatment alone had poor results } \\
\text { (performed in more seek patients) CABG > } \\
\text { PCl if mild MR CABG + MVR associated with } \\
\text { poor prognosis but more severe patients }\end{array}$ \\
\hline $\begin{array}{l}\text { Salmasi } \\
\text { et al. (46) }\end{array}$ & Meta-analysis & Comparative & $\begin{array}{l}\mathrm{CABG} \text { alone vs. } \mathrm{CABG}+\mathrm{MV} \\
\text { surgery }\end{array}$ & $x$ & & Only ICM & $\mathrm{x}$ & & $\begin{array}{l}\text { Only } \\
\text { moderate }\end{array}$ & & & N/A & & & N/A & $\begin{array}{l}\text { MV surgery is not associate with any } \\
\text { improvement in long-term survival or } \\
\text { functional class }\end{array}$ \\
\hline $\begin{array}{l}\text { Chan } \\
\text { et al. (24) }\end{array}$ & Randomized & Comparative & $\begin{array}{l}\text { CABG alone (39 patients) vs. } \\
\text { CABG + MVr ( } 34 \text { patients) }\end{array}$ & $x$ & & Only ICM & $\mathrm{x}$ & & $\begin{array}{l}\text { Mean ERO } \\
0.18-0.21 \\
\mathrm{~cm}^{2}\end{array}$ & $\mathrm{x}$ & $\mathrm{x}$ & Mean $40 \%$ & & $\mathrm{x}$ & $\begin{array}{l}\text { Mean LVEDD } \\
56 \mathrm{~mm}\end{array}$ & $\begin{array}{l}\text { Greater improvement in peak oxygen } \\
\text { consumption, greater LV reverse remodeling } \\
\text { but no improvement of survival at } 1 \text { year }\end{array}$ \\
\hline $\begin{array}{l}\text { Michler } \\
\text { et al. (47) }\end{array}$ & Randomized & Comparative & $\begin{array}{l}\text { CABG alone (151 patients) vs. } \\
\text { CABG + MVr ( } 150 \text { patients) }\end{array}$ & $\mathrm{x}$ & & Only ICM & $\mathrm{x}$ & & $\begin{array}{l}\text { Mean ERO } \\
0.2 \mathrm{~cm}^{2}\end{array}$ & $\mathrm{x}$ & $\mathrm{x}$ & Mean $40 \%$ & & $\mathrm{x}$ & $\begin{array}{l}\text { Mean LVESVi } \\
54 \text { and } \\
50 \mathrm{~mL} / \mathrm{m}^{2}\end{array}$ & $\begin{array}{l}\text { Combined strategy did not result in a higher } \\
\text { degree of LV reverse remodeling. Increased } \\
\text { number of untoward events and survival was } \\
\text { not different }\end{array}$ \\
\hline $\begin{array}{l}\text { Kang } \\
\text { et al. (25) }\end{array}$ & Prospective & Comparative & $\begin{array}{l}\text { CABG alone ( } 5 \text { patients) vs. } \\
\text { CABG + MVr ( } 50 \text { patients) }\end{array}$ & $x$ & & Only ICM & $\mathrm{x}$ & & $\begin{array}{l}\text { Mean MR } \\
\text { grade } 2.5 \\
\text { and } 2.8\end{array}$ & & $x$ & $\begin{array}{l}\text { Mean LVEF } \\
36.2 \% \text { and } \\
33.8 \%\end{array}$ & & $x$ & $\begin{array}{l}\text { Mean LVEDD } \\
59 \text { and } \\
61 \mathrm{~mm}\end{array}$ & $\begin{array}{l}\text { No improvement in long-term survival when } \\
\text { mitral repair is associated with CABG surgery }\end{array}$ \\
\hline $\begin{array}{l}\text { Deja } \\
\text { et al. (26) }\end{array}$ & Randomized & Comparative & $\begin{array}{l}\text { CAD amenable to CABG } \\
\text { randomized to medial therapy } \\
\text { with (613 patients) or without } \\
\text { CABG ( } 599 \text { patients) }\end{array}$ & $x$ & & Only ICM & $\mathrm{x}$ & $\mathrm{x}$ & $\begin{array}{l}\text { Mild in } \\
46 \% \geq 3+\text { in } \\
18 \%\end{array}$ & & $\mathrm{x}$ & $\begin{array}{l}\text { Only LVEF } \\
\leq 35 \%\end{array}$ & $\mathrm{x}$ & $\mathrm{x}$ & $\begin{array}{l}\text { Mean LVESVi } \\
72 \text { to } \\
89 \mathrm{~mL} / \mathrm{m}^{2}\end{array}$ & $\begin{array}{l}\text { In mild MR: } \mathrm{CABG}=\text { medical treatment; } \\
\text { in moderate to severe MR (104 patients): } \\
\text { surgery may improve survival but it remains } \\
\text { unclear if this advantage is due to the CABG } \\
\text { itself or the treatment of the associated MR }\end{array}$ \\
\hline $\begin{array}{l}\text { Kamperidis } \\
\text { et al. (27) }\end{array}$ & Retrospective & Single arm & $\begin{array}{l}130 \text { patients treated with } \\
\text { surgical } \mathrm{MVr}\end{array}$ & & $x$ & $\begin{array}{l}78 \% \text { non- } \\
\text { ischemic }\end{array}$ & $x$ & $x$ & $\begin{array}{l}\text { Severe } \\
\text { define as } \\
\text { ERO } \geq 0.2 \\
\mathrm{~cm}^{2}\end{array}$ & & $x$ & Mean 31\% & $x$ & & $\begin{array}{l}\text { Mean LVEDV } \\
188 \mathrm{~mL}\end{array}$ & $\begin{array}{l}\text { MVr help reducing LV volumes, increase } \\
\text { LV forward stroke volume and LV forward } \\
\text { ejection fraction but not LVEF }\end{array}$ \\
\hline $\begin{array}{l}\text { Kamperidis } \\
\text { et al. (48) }\end{array}$ & Retrospective & Single arm & $\begin{array}{l}76 \text { patients underwent } \\
\text { surgical repair }(71 \%) \text { or } \\
\text { MitraClip repair }(29 \%)\end{array}$ & & $\mathrm{x}$ & $\begin{array}{l}100 \% \text { non- } \\
\text { ischemic }\end{array}$ & $x$ & $x$ & $\begin{array}{l}\text { Mean ERO } \\
0.21 \mathrm{~cm}^{2}\end{array}$ & & $x$ & Mean 34\% & & $x$ & $\begin{array}{l}\text { Mean LVEDVi } \\
87 \mathrm{~mL} / \mathrm{m}^{2}\end{array}$ & $\begin{array}{l}\text { Repair improved LV forward flow and induced } \\
\text { LV reverse remodelling but did not change LV } \\
\text { systolic function (no survival data) }\end{array}$ \\
\hline $\begin{array}{l}\text { Obadia } \\
\text { et al. (19) }\end{array}$ & Randomized & Comparative & $\begin{array}{l}\text { Medical therapy alone ( } 155 \\
\text { patients) or associated with } \\
\text { MitraClip (152 patients) in } \\
\text { patients not considered to be } \\
\text { candidates for MV surgery }\end{array}$ & $x$ & $x$ & ICM in $60 \%$ & $x$ & $x$ & $\begin{array}{l}\text { Mean ERO } \\
0.31 \mathrm{~cm}^{2}\end{array}$ & & $x$ & Mean 33\% & $x$ & & $\begin{array}{l}\text { Mean LVEDVi } \\
134 \text { and } \\
136 \mathrm{~mL} / \mathrm{m}^{2}\end{array}$ & $\begin{array}{l}\text { Survival and hospitalization rate for heart } \\
\text { failure at } 1 \text { year did not differ significantly } \\
\text { between patients who underwent MitraClip } \\
\text { therapy and those who received medical } \\
\text { therapy alone }\end{array}$ \\
\hline $\begin{array}{l}\text { Stone } \\
\text { et al. }(20)\end{array}$ & Randomized & Comparative & $\begin{array}{l}\text { Medical therapy alone ( } 312 \\
\text { patients) or associated with } \\
\text { MitraClip ( } 302 \text { patients) in } \\
\text { patients with STS score } \geq 8 \%\end{array}$ & $x$ & $x$ & ICM in 60\% & & $x$ & $\begin{array}{l}\text { Mean ERO } \\
0.4 \mathrm{~cm}^{2}\end{array}$ & & $x$ & Mean 31\% & $x$ & & $\begin{array}{l}\text { Mean LVEDV } \\
191 \text { and } \\
194 \mathrm{~mL}\end{array}$ & $\begin{array}{l}\text { Transcatheter MVr resulted in a lower rate of } \\
\text { hospitalization for heart failure and lower all- } \\
\text { cause mortality within } 24 \text { months of follow-up }\end{array}$ \\
\hline $\begin{array}{l}\text { Magne } \\
\text { et al. (17) }\end{array}$ & Retrospective & Comparative & $\begin{array}{l}\text { MVR (184 patients) vs. MVr } \\
\text { (186 patients) }\end{array}$ & $x$ & & $\begin{array}{l}\text { CABG } \\
\text { associate in } \\
84 \%(M V r) \text { and } \\
94 \% \text { (MVR) }\end{array}$ & & $x$ & $\begin{array}{l}\text { Severe in } \\
88 \%(\mathrm{MVr}) \\
\text { and } 97 \% \\
\text { MVR }\end{array}$ & $x$ & & $\begin{array}{l}\text { Mean LVEF } \\
43 \% \text { and } \\
45 \%\end{array}$ & & $x$ & $\begin{array}{l}\text { Mean LVEDD } \\
57 \text { and } 58 \mathrm{~mm}\end{array}$ & $\begin{array}{l}\text { MVr is not superior to replacement with } \\
\text { regard to operative and overall mortality in } \\
\text { patients with ischemic MR }\end{array}$ \\
\hline $\begin{array}{l}\text { Acker } \\
\text { et al. (18) }\end{array}$ & Randomized & Comparative & $\begin{array}{l}\text { MVR (125 patients) vs. MVr } \\
\text { (126 patients) }\end{array}$ & $x$ & & $\begin{array}{l}\text { CABG } \\
\text { associate in } \\
75 \%\end{array}$ & & $x$ & $\begin{array}{l}\text { Mean ERO } \\
0.4 \text { and } \\
0.39 \mathrm{~cm}^{2}\end{array}$ & $x$ & & $\begin{array}{l}\text { Mean LVEF } \\
42 \% \text { and } \\
40 \%\end{array}$ & & $x$ & $\begin{array}{l}\text { Mean LVESVi } \\
61 \text { and } \\
67 \mathrm{~mL} / \mathrm{mm}^{2}\end{array}$ & $\begin{array}{l}\text { No significant difference in LV reverse } \\
\text { remodeling or survival at } 12 \text { months between }\end{array}$ \\
\hline $\begin{array}{l}\text { Calafiore } \\
\text { et al. (49) }\end{array}$ & Retrospective & Comparative & $\begin{array}{l}82 \text { repairs and } 20 \\
\text { replacements (depending } \\
\text { on end-systolic distance } \\
\text { between the coaptation point } \\
\text { of mitral leaflets and the plane } \\
\text { of mitral annulus) }\end{array}$ & $x$ & & $\begin{array}{l}\text { CABG } \\
\text { associate in } \\
92 \%\end{array}$ & & $x$ & $\begin{array}{l}\geq 3+\text { in } 82 \% \\
\text { and } 84 \%\end{array}$ & $x$ & $x$ & Mean 37\% & $x$ & & $\begin{array}{l}\text { Mean LVEDVi } \\
116 \text { and } \\
109 \mathrm{~mL} / \mathrm{m}^{2}\end{array}$ & $\begin{array}{l}\text { Correction of chronic ischemic MR through } \\
\text { either repair or replacement provides a good } \\
5 \text {-year survival rate }\end{array}$ \\
\hline $\begin{array}{l}\text { Lee } \\
\text { et al. (50) }\end{array}$ & Retrospective & Single arm & $\begin{array}{l}\text { Risk of MR recurrence in } \\
104 \text { patients who underwent } \\
\text { annuloplasty for nonischemic } \\
\text { dilated cardiomyopathy }\end{array}$ & & $x$ & & $x$ & $x$ & $\begin{array}{l}\geq 3+\text { in } 82 \% \\
\text { and } 84 \%\end{array}$ & $x$ & $x$ & $\begin{array}{l}\text { Mean LVEF } \\
28 \% \text { and } \\
24 \%\end{array}$ & $x$ & & $\begin{array}{l}\text { Mean LVEDV } \\
242 \text { and } \\
349 \mathrm{~mL}\end{array}$ & $\begin{array}{l}\text { Postoperative mitral competence highly } \\
\text { dependent on preoperative distal anterior } \\
\text { leaflet mobility }\end{array}$ \\
\hline $\begin{array}{l}\text { Magne } \\
\text { et al. (51) }\end{array}$ & Retrospective & Comparative & $\begin{array}{l}\text { Risk of MR recurrence in } \\
51 \text { consecutive patients } \\
\text { undergoing restrictive } \\
\text { annuloplasty with or without } \\
\text { CABG for ischemic MR }\end{array}$ & $x$ & & $\begin{array}{l}\text { CABG } \\
\text { associated in } \\
>90 \%\end{array}$ & $x$ & $x$ & $\begin{array}{l}\text { Vena } \\
\text { contracta } \\
\text { width } 5.4 \\
\text { and } 5.9 \\
\mathrm{~mm}\end{array}$ & $x$ & $x$ & $\begin{array}{l}\text { Mean LVEF } \\
37 \% \text { and } \\
34 \%\end{array}$ & & $x$ & $\begin{array}{l}\text { Mean LVEDV } \\
168 \text { and } \\
180 \mathrm{~mL}\end{array}$ & $\begin{array}{l}\text { Patients with high posterior leaflet restriction } \\
\text { should thus be considered poor candidates } \\
\text { for restrictive MVA }\end{array}$ \\
\hline
\end{tabular}

